DOI: 10.1515/ausp-2015-0017

\title{
How (Not) to Fail as a Multimedia Translator
}

\author{
Attila IMRE \\ Department of Applied Linguistics \\ Sapientia Hungarian University of Transylvania (Târgu Mureş, Romania) \\ attilaimre@ms.sapientia.ro
}

\begin{abstract}
The article is trying to highlight the major skills of a presentday translator, without which failure is assured. Although we start with general (classical) requirements, particular ones will be discussed, such as the gradual shift from PRAT (paper-and-rubber-assisted translation) to CAT (computer-assisted translation). We argue that professional translators in the $21^{\text {st }}$ century must make use of personal computers and specific software designed to support translation: translation memories (TM), term bases (TB) and translation environments (TE), which already have builtin machine translation (MT) possibility as well. This shift also entails that translators have to deal with further impediments as well: the so-called "text"-to-be-translated has changed to "whatever"-to-be-translated. We argue that would-be translators are hardly ever prepared for this new type of multimedia challenge (e.g. surtitles), thus leaving room for technical experts to discover their skills in translating multimedia. It is our belief that managing translations is directly linked with managing translators, and there are more traps for translators in the $21^{\text {st }}$ century than a layman would think. Consequently, we would like to offer some tips how to build and acquire translation databases in order to catch up with the $21^{\text {st }}$ century rush hour in the field of translation.
\end{abstract}

Keywords: multimedia, translator's skills, CAT-tools, memoQ

\section{Introduction}

The present article focuses on a specific area of translations, namely multimedia translations. The necessity to discuss this aspect of translations derives from the emerging demand for this type of translation, which often causes a real headache for many translators.

Our starting point is that a skilled translator must have the basic "know-how" how to approach this type of translation as well, even if the technical skills required seem to be rather challenging. But without a few preliminary definitions, even the previous statement is debatable: why should technical translation - or 
at least involving technical background knowledge regarding software - be more challenging than a literary one?

One might have the feeling that a translator - by nature - is not "compatible" with technical challenges, if we have in mind a "stereotypical" translator, that is, a translator with philological background. However, in our times this is a rather misleading approach. Thus, in the following we will discuss various definitions of multimedia, the skills of a translator, so that we can lead up to multimedia translations and possibilities of CAT-tools.

\section{Definitions}

We have argued in the introductory part that certain definitions seem to be inevitable. We think that the definition of multimedia, skill and translator is important to discuss the possibilities of a successful multimedia translation.

\subsection{Multimedia}

It is rather strange that the keyword multimedia is not even listed in the Shorter Oxford English Dictionary (SOED) published in 2002 (Trumble and Stevenson 2002). However, the online version ${ }^{1}$ already offers a definition, according to which multimedia is "an extension of hypertext allowing the provision of audio and video material cross-referenced to a computer text". No details are provided in the definition, but - for a start - we can realize that text is combined with auditory and visual elements. The Free Online Dictionary offers further details: ${ }^{2}$

1) The combined use of media, such as movies, music, lighting, CD-ROMs, and the Internet, as for education or entertainment.

2) The combined use of media, such as television, radio, print, and the Internet, as for advertising or publicity.

These two definitions already mention clearer aspects of multimedia (movies, music, the Internet), but we think that a technical definition from Techterms ${ }^{3}$ will complete the picture:

... multimedia is the integration of multiple forms of media. This includes text, graphics, audio, video, etc. For example, a presentation involving audio and video clips would be considered a "multimedia presentation." Educational software

1 http://www.oxforddictionaries.com/definition/english/multimedia, 15. 06. 2014.

2 http://www.thefreedictionary.com/multimedia, 15. 06. 2014.

3 http://www.techterms.com/definition/multimedia, 15. 06. 2014. 
that involves animations, sound, and text is called "multimedia software." CDs and DVDs are often considered to be "multimedia formats" since they can store a lot of data and most forms of multimedia require a lot of disk space.

Thus multimedia is connected to computers, after all. We can say that "computers have pervaded our lives, practically it is hard to find a field where they are not present, so in our opinion it is non-productive to discuss their raison d'être" (Imre 2013: 103). As one of the consequences, computers are more and more used in translations as well, thus we witness - in Bowker's words - "a dramatic increase in the use of CAT tools and note that this increase will be needs-driven" (Bowker 2002: 12). She further mentions the trendy software localization industry, relying on Thibodeau, who explains that the major reason for localizing software products is economic, hence we have the "pressure on translators to work more quickly with maintaining high-quality output". Consequently, translators have to participate in launching Web sites, product releases in multiple languages simultaneously, which results in "simship", that is simultaneous shipment (Bowker 2002: 13).

Of course, arguments for and against this (r)evolution in technology are constantly brought up. We would like to offer Gouadec's approach, as he divides this revolution into a "friendly" and a "not so friendly" one (2007: 286). In his view, even the most ardent supporters of this revolution should accept certain drawbacks. One of them is that "computerisation has changed translation from an amateur pursuit into a cottage industry and now, into an industrial process", leading to an increased volume of translatable material (by providing the tools needed to process such large volumes). Naturally, due to this, translators are faced with "increasingly heavy investments if they want to meet their work providers' requirements and deserve the 'technologically efficient' label". A possible fail of translators, in Gouadec's terms - is when they are labelled as 'pure text translators', not being able to handle more or less sophisticated software or computer code processing. Although Gouadec's book was published in 2007, he already mentioned the standard:

1. word processor;

2. desk publishing;

3. translation memory management;

4. terminology management;

5. full Internet functionalities.

What he mentions above standard is image processing, voice recognition, HTML, XML, XHTML, XSL editors, and new types of translation markets, which - in our opinion - is multimedia translation. 


\subsection{Skills of a Translator}

Seemingly, it is important to clarify major skills of a present-day translator, deriving from the previous section.

As there are overlapping terms, we have searched for the definition of competence, which may be "a specific range of skill, knowledge, or ability", or in linguistics "the knowledge that enables one to produce and comprehend a language". ${ }^{4}$ The SOED defines competence as the "power, ability, capacity for a task" (Trumble and Stevenson 2002: 467), but the majority of specialized literature focuses on the skills of translators, as its definitions are closer to what is expected from a translator. Thus skill may be defined as "proficiency, facility, or dexterity that is acquired or developed through training or experience" or "a developed talent or ability", ${ }^{5}$ whereas the SOED equals it with "knowledge" or an "ability to do something (esp. manual or physical) well; proficiency, expertness, dexterity; an ability to do something, acquired through practice or learning (freq. in pl.)". Consequently, a skilled person is "highly trained or experienced, esp. in a particular accomplishment" (Trumble and Stevenson 2002: 2857).

The skills of a translator are - seemingly - very clearly described by the Directorate-General for Translation (DGT) for the European Commission, one of the largest translation services in the world ${ }^{6}$ They offer a translator profile with a guideline for basic requirements (e.g. initiative, capacity to work under pressure, self-discipline), but what is more interesting from our point of view is that they mention specific skills, divided into three parts:

1. language skills (at least three languages: mother tongue and two more, one of which must be English, French or German);

2. thematic skills, which means "familiarity with economics, financial affairs, legal matters, technical or scientific fields";

3. translation skills with various capacities: "understanding texts in the source language and to render them correctly in the target language" with proper style and register, "researching topics and terminology quickly and efficiently", and "a capacity to master computer-assisted translation and terminology tools, as well as standard office-automation software".

The above-listed skills briefly summarize the requirements for present day translators described in various books on translation. This means that failing any of them should lead to the failure of the translator as such. Naturally, language skills vary, let alone their combination in case of translators. Yet, we

4 http://www.thefreedictionary.com/competence, 15. 06. 2014.

5 http://www.thefreedictionary.com/skill, 15. 06. 2014.

6 http://ec.europa.eu/dgs/translation/workwithus/staff/profile/index_en.htm, 15. 06. 2014. 
may observe that the more languages one can 'master', the higher the chance to remain competitive. Still, some will argue that the knowledge of more than 4 or 5 languages is to the detriment of the earlier learned languages.

Thematic skills may also vary, as the ones described above only refer to the European Commission's needs. Yet, only a limited number of translators are employed at DGT, however large it is, so the majority of them should consider further fields as well. Experts have been constantly signaling the popularity of text types to be translated (Kis and Mohácsi-Gorove 2008), and even if McKay (2006: 22) analyses the US segment alone, the statistics are discouraging: "Americans don't tend to read literature in translation, so there is a small market for the work of literary translators; in 2004, only 891 of the 195,000 new books printed in English were adult literature in translation." This is no more than $0.004 \%$ of all published books in the USA, whereas this may be around 1\% in Romania, as Rodica Dimitriu estimated it during a conference (Imre 2013). No wonder that the market for literary translations is declining, but if this is true, one might ask, what part of the translation industry is growing? ${ }^{7}$

A possible answer is given by Gouadec, who offered a further not-so-friendly aspect of the technological revolution, namely globalization, which, in his opinion, is "the logical outcome of computerization". As he explains, "whoever can offer the lowest rates anywhere in the world has a good chance of getting the contracts, or at least that competition is now putting pressure on rates the world over" (Gouadec 2007: 286). Furthermore, we may add that the form(at) of all specialized texts should be considered, as technical texts may take the shape of multimedia texts for various types of gadgets (descriptions, help files for mobile phone applications, tablets, phablets and what not).

As a result, a different type of skill a translator should master is connected to finances. A translator not capable of handling clients efficiently will certainly lead to failure. This skill includes both the "acquiring" of new clients and preserving the older ones, so an extra skill is also needed: negotiation skills, guided by a proper knowledge of people leading to emotional intelligence (EQ).

\section{Multimedia translation}

Multimedia translation is different from 'classical text' translation in the sense that the so-called "text"-to-be-translated has changed to "whatever"-to-betranslated. This 'whatever' includes sources from the four types of media (TV, radio, printed and Internet), completed with audiovisual and mobile devices as well. Audiovisual translation may include subtitling, dubbing, voice-over, surtitling, scanlation, fan translation or (software) localization (Imre 2013: 191-

7 The fact that it is expanding is reported in numerous studies regarding the translation industry. 
200). However, other types should also be considered, such as closed captioning (CC), various adaptations, respeaking, mobile translation (machine translation for hand-held devices). The immense industry of video games has led to a much larger video games translation (as instead of the usually English language, multiple languages are involved).

The question is whether a translator is capable of handling these types of translation or not. Some of them are rather reluctant to enter this field, whereas others are more than enthusiastic about. Maybe around two decades ago a proficient translator had to deal with Microsoft Windows and Microsoft Office, which involved a certain level of computer-literacy: starting the computer and the office software, but the bulk of the job was still centered on the text. When the translation was ready, saving options and sending attachments (occasionally in zipped form) would have sufficed. High level formatting options were not available, let alone quality assurance from the point of view of consistency. Nevertheless, translated texts were - on average - of better quality as the majority of translators had a solid basis of the languages, and the focus was on the text anyway. However, in our times when the text is only one part of the translation job (combined with sounds and images in various layouts), this is much more complicated. We have faster computers with much more improved desktop publishing possibilities on various platforms, as Microsoft has serious competitors, such as Apple or different Linux distributions with OpenOffice or LibreOffice. The technical know-how requirements are much more difficult, struggling hard to maintain the balance between the technical and actual translation part. Somers mentions keyboard layout, word-processor (text justification, automatic hyphenation programs, auto-correction facilities - spell checker), date and time stamps, contents list and index creation for longer documents, word counting, font types, desktop publishing, optical character recognition (OCR), spell-checker, grammar-checker, dictionary mono, dictionary bilingual, dictionary multilingual, localization tool, translation, speech products (Somers 2003), and his list can never be complete. For instance, in the age of 'multi', a proper investment for a translator is a multifunctional machine with printing, ${ }^{8}$ scanning, copying and faxing options, but even when scanning, $\mathrm{ADF}^{9}$ is more than welcome.

A Hong-Kong based translation agency is looking for people who are familiar with software localization (screenshot capture, InDesign, Passolo, Wintrans, etc.), website/webpage engineering expertise (HTML, ASP, XML formats), flash engineering (support for European and Asian double-byte languages), voice recording and post-production software, multilingual DTP and graphic typesetting (Photoshop, CorelDraw) and the good knowledge of both PC and Mac computers. We cannot estimate how many translators in Europe are familiar with

8 Preferably duplex, that is the automatic printing on both sides of the paper.

9 Automatic Document Feeder. 
the above listed items, but we draw the conclusion that the stereotypical image of a translator is fading.

This means that those above forty are inclined to think that the majority of translators have philological background, who can handle technology (more or less). However, it has already been mentioned (McKay 2006) that more and more engineers switch to translation, as they are much more familiar with technology and they also know at least two languages, including the technical specialization. We believe that philological translators accustomed to synonyms and antonyms, metaphorical expressions and wordplays are not prepared for this type of 'invasion' of the industry, and can handle only with difficulties technical texts full of abbreviations, stock phrases of rules and regulations (cf. Help files, product descriptions, etc.). What is more, laypeople still think that a bilingual person can translate without any problems (Simigné Fenyő 2006: 9), although it has long been proven that this is not the case. The UNESCO General Conference in Nairobi"10 (1976, section V.14.d) stated that "a translator should as far as possible translate into his or her own mother tongue or into a language of which he or she has a mastery equal to that of his or her mother tongue", but we tend to think that this recommendation is looked over.

There is no place for presenting further misconceptions here regarding translators, but spell-check, proofreading are not taken for granted during translation/creating texts (cf. Samuelsson-Brown 2010: 2-3). Newmark (1969: 85) states that only intelligent people can become translators, and we know that the target text has become much more important than the source text (cf. fidelity, equivalence, two masters), especially focusing on the cultural background. Gouadec talks about PRAT, which is Pencil and Rubber-Assisted Translator, concluding that this is "clearly on the way out", as computer-based translation has taken over (2007: 109). If one might think that his statement is similar to sounding the alarm or drawing the blinds, then we are in trouble. Albert also highlights the importance of technology, which cannot be looked over by professional translators any more (cf. Albert 2011: 9).

A possible way out is - in our opinion - the good knowledge of an advanced computer-assisted translation tool (CAT-tool), which leads us to the next section.

\section{Possibilities of CAT-tools against failure}

Computers have released our minds from the constraints of retention to a great extent and instead of keeping things in mind we can focus on much more important activities and programs involving innovation, reflection, creativity, comparison, construction, combination, etc. (Fodor 2013: 8).

10 Accessible at http://unesdoc.unesco.org/images/0011/001140/114038E.pdf, 09.03.2013. 
Since technology entered the field of translation, we can talk about machine translation. Even if the infamous ALPAC report from 1966 (Hutchins 2003) seemed to stop further research, today both machine translation (MT) and its initial rivals - CAT-tools - are thriving. Due to globalization, internationalization and localization, machine translation is a common aspect of CAT-tools, which have already encapsulated MT. For instance, a top quality CAT-tool vendor, Kilgray commercializes memoQ, which has built-in features to provide machine translation. As of 2014, a regular memoQ can activate no fewer than nine types of MT compared to only six in 2013 or none in 2008. But it is more than that.

Present day CAT-tools can offer almost all the necessary technical tools a skilled translator may need, listed below:

1. We can include multiple documents of various formats having the possibility to translate them in parallel, even partially within a single project.

2. A translation memory (TM) is also provided, which can store all the source and target sentences in pairs (called segments). TMs are highly effective as they can be exported, imported, constantly signaling previously translated units, directly contributing to quality. Furthermore, memoQ has a very specific type of TM, called LiveDocs, into which we can upload document pairs that can be easily used later as a TM for a new, similar document to be translated.

3. A term base (TB) may be either created, exported or imported allotted to a translation job (project). As of 2013, memoQ can incorporate dual column Excelbased lists of terms as TB, which is of immense help for specialized terminology.

4. There are many further features that directly contribute to productivity, depending on the type of CAT-tool. memo $Q$ can download various dictionaries and activate them during translation, improving spell-check and correcting typo-mistakes. A built-in Statistics option will help visualize the workload and possible gain of a translation, even in different formats. ${ }^{11}$ The Pre-translate function will search for in the TM and insert all the matches (based on a previously established threshold match percentage) into the new translation job. Many TM and TB plugins can be activated, as well as error-correction functions or various keyboard shortcuts, and so on.

5. What we would particularly highlight is the format-friendly aspect of CATtools, being able to use multiple document formats (including pdf) and the almost perfect capability of preserving the original layout (at least in case of memoQ), which is not a negligible aspect for multimedia translations.

The logical question is whether 'average' translators can handle CAT-tools. We tend to think that we have a positive answer as we are directly involved in CATtool instruction, and the above-listed possibilities may be acquired in a relatively short period of time. Of course, the investment price should also be considered.

11 For instance, it can show statistics in memoQ or TRADOS-like style, which is the world leading CAT-tool provider. 


\section{Conclusions}

We have seen that in the age of technology, there are no more 'simple' text translations, but 'projects' with multiple functions. Although one or two decades ago the debate over MT or CAT seemed important in relationship with human translators, today the problem is irrelevant: we tend to think that the first step was taken when MT became a built-in function of CAT-tools, and instead of witnessing an MT versus CAT-tool fight, we are slowly but surely getting to understand that both MT and CAT-tools are potential aids for human translators.

Ede Teller, a famous theoretical physicist, once said that "A person who cannot use a computer will be considered illiterate in the $21^{\text {st }}$ century". ${ }^{12}$ Today his words are very timely. If everybody should be able to use a computer, then translators have to be experts in using it, especially specific translation tools.

The key to success may lie in the combination of respecting deadlines (the managing aspect of translation), keeping in touch on forums, ${ }^{13}$ joining associations of know-how, ${ }^{14}$ pleasing the clients in a new way, discovering that we are "living in a crowd" (Gouadec 2007: 219).

As mentioned in a previous work (Imre 2013: 104), our 'global world' seems to undergo a complete technological change, our free time is more and more connected to powerful online activities (education, socializing, games), which are aided by technology (Lambert 2006a: 102-103). As for translation, we can witness an intensifying interest towards marginalized people as well, such as translating for the blind and the deaf, but more and more monolingual written versions and monolingual subtitles appear, which clearly mark the growing importance of translation in the world of technology (Lambert 2006b: 144). On the other hand, the growing number of amateur translators and translations is also facilitated by the ease of access via computers (cf. fantranslations, fansubbing).

Snell-Hornby mentions the new McWorld, in which "virtually unlimited quantity of parallel texts as a potential aid in translation" may be found (SnellHornby 2006: 132-133), leading to a certain McLanguage, "a particular brand of American English", that is "reduced in stylistic range and aided by abbreviations, icons, acronyms and graphic design" and "tailor-made for fast consumption". Yet, a translator must be above 'standard' language use, even if colloquial forms are spreading, and there is a greater "tolerance of language mistakes/ typing

12 The saying widely circulates in Hungarian: "Az olyan ember, aki nem ért a számítógépekhez, a XXI. században anafabétának fog számítani.” The English version was used by Rózsa Hoffman, the Minister of State for Education, Hungary, greeting the 19th Central European Olympiad in Informatics, 2012: http://people.inf.elte.hu/szlavi/CEOI2012/NL0/NL0_Tata_v12.pdf, 15. 06. 2014.

13 An aspect which has been neglected before, as a stereotypical translator is a "detail-oriented introvert" (McKay 2006: 32).

14 As encouraged by Tibor Környei, the founder and moderator of the Translators' Electronic Forum in Hungary (mfefo). 
errors" (Snell-Hornby 2006: 128). She also adds that multimedia communication resulted in many layout tricks, images, sounds and advertising techniques, which can be handled excellently in CAT-tools, as previously mentioned.

Although the bulk of all text-types to be translated is technical, we are certain that translators are not 'lost in translation' as their competence is "invariable" (Snell-Hornby), albeit its content is changing.

In our view, the ultimate challenge for translators (whether they are of philological or non-philological background) is to 'keep up with the Joneses', in which case the Joneses stand for the technical know-how of translations. Failure may be avoided if a proper CAT-tool is used, which should be considered indispensable for a proficient translator.

\section{References}

Albert, Sándor. 2011. "A fövényre épített ház”. ["The House Built on Sand.”] Budapest: Áron Kiadó.

Bowker, Lynne. 2002. Computer-Aided Translation Technology: A Practical Introduction. University of Ottawa Press.

Fodor, László. 2013. Gondolatok a nevelésről. [Thoughts about Education.] Magiszter 11(1): 5-11.

Gouadec, Daniel. 2007. Translation as a Profession. Amsterdam / Philadelphia: John Benjamins Publishing.

Hutchins, John. 2003. ALPAC: The (In)Famous Report. In: Readings in Machine Translation. Nirenburg, Sergei et al. (eds.), 131-136. Cambridge, MA; London, England: The MIT Press.

Imre, Attila. 2013. Traps of Translation. Braşov: Editura Universității "Transilvania."

Kis, Balázs, \& Anna Mohácsi-Gorove. 2008. A fordító számítógépe [The Translator's Computer]. Bicske: Szak Kiadó.

Lambert, José. 2006a. Literatures, Translation and (de)colonization (1995). In: Functional Approaches to Culture and Translation, 87-104. Amsterdam / Philadelphia: John Benjamins Publishing Company.

Lambert, José. 2006b. Problems and Challenges of Translation in an Age of New Media and Competing Models (1997). In: Functional Approaches to Culture and Translation, 131-146. Amsterdam / Philadelphia: John Benjamins Publishing Company.

McKay, Corinne. 2006. How to Succeed As a Freelance Translator. Two Rat Press. Newmark, Peter. 1969. Some Notes on Translation and Translators. In: Incorporated Linguist 8(4): 79-85. 
Samuelsson-Brown, Geoffrey. 2010. A Practical Guide for Translators. Multilingual Matters.

Simigné Fenyő, Sarolta. 2006. A fordítás mint közvetítés. [Translation as Mediation.] Miskolc: STÚDIUM Rendezvények és Nyelvtanfolyamok.

Snell-Hornby, Mary. 2006. The Turns of Translation Studies: New Paradigms or Shifting Viewpoints? Amsterdam / Philadelphia: John Benjamins Publishing.

Somers, Harold. 2003. Translation Technologies and Minority Languages. In:

Somers, Harold L. (ed.), Computers and Translation: A Translator's Guide, 87-103. Benjamins Translation Library, 35. Amsterdam / Philadelphia: John Benjamins Publishing Company.

Trumble, William R., \& Angus Stevenson (eds.). 2002. The Shorter Oxford English Dictionary, vol. I-II. $5^{\text {th }}$ ed. Oxford: Oxford University Press.

\section{Online sources}

http://ec.europa.eu/dgs/translation/workwithus/staff/profile/index_en.htm, 15. 06. 2014.

http://people.inf.elte.hu/szlavi/CEOI2012/NL0/NL0_Tata_v12.pdf, 15.06.2014. http://unesdoc.unesco.org/images/0011/001140/114038E.pdf, 09.03.2013. http://www.oxforddictionaries.com/definition/english/multimedia, 15. 06. 2014. http://www.techterms.com/definition/multimedia, 15. 06. 2014. http://www.thefreedictionary.com/competence, 15. 06. 2014. http://www.thefreedictionary.com/multimedia, 15. 06. 2014. http://www.thefreedictionary.com/skill, 15. 06. 2014. 